\title{
ANALISIS PENGARUH KUALITAS PRODUK DAN CITRA MEREK PADA LOYALITAS KONSUMEN YANG MENGGUNAKAN APLIKASI DANA DI BAKMI GM BINTARO X-CHANGE
}

\author{
Rr. Renny Anggraini \\ Staf Pengajar Fakultas Ekonomi Universitas Pamulang \\ dosen universitas pamulang, email : dosen01802@unpam.ac.id
}

\begin{abstract}
ABSTRAK
Penelitian ini bertujuan untuk mengetahui pengaruh kualitas produk dan citra merek pada loyalitas konsumen yang menggunakan aplikasi pembayaran digital DANA di Bakmi GM Bintaro Xchange. Penelitian studi kasus dengan metode kuantitatif non-random sampling dengan sampel penelitian 100 konsumen yang menggunakan aplikasi DANA di Bakmi GM Bintaro Xchange. Untuk melihat pengaruh variabel bebas pada variabel terikat, pengolahan data menggunakan software SPSS. Hasil dari penelitian membuktikan kualitas produk dan citra merek berpengaruh penting pada timbulnya loyalitas konsumen yang menggunakan aplikasi DANA di Bakmi GM Bintaro Xchange.
\end{abstract}

Kata Kunci: Kualitas Produk, Citra Merek, Loyalitas Konsumen

\begin{abstract}
This research aims to determine effect of product quality and brand image on consumer loyalty using digital payment application DANA at Bakmi GM Bintaro Xchange. Research case study with quantitative methods with quantitative non-random sampling with a sample of 100 consumer research using the DANA application in Bakmi GM Bintaro Xchange. To see effect of independent variables on the dependent variable, data processing using SPSS software. Results of the research prove that product quality and brand image have an important effect on the emergence of consumer loyalty using the DANA application at Bakmi GM Bintaro Xchange.
\end{abstract}

Keyword: Product Quality, Brand Image, Customer Loyalty 


\section{PENDAHULUAN}

\subsection{Latar Belakang}

Kemajuan dan perkembangan teknologi membuat pekerjaan semakin mudah. Seperti internet yang membantu orang untuk dapat mengetahui hal-hal terbaru. Industri keuangan seperti teknologi keuangan dan perbankan digital. Teknologi digital tersebut telah menjadi kebutuhan bagi semua orang. Dengan begitu teknologi digital dapat mengembangkan target pasar semakin luas.

Hampir seluruh bank sekarang memberikan layanan seperti internet banking, mobile banking, emoney untuk customernya, hanya dengan mendownload aplikasi tersebut dari seluler. Negara-negara internasional telah menunjukan beberapa dampak dari munculnya teknologi digital untuk stabilitas sistem keuangan dan pertumbuhan ekonomi. Pertama, menggunakan debit dan kredit dengan biaya rendah, tentu hal ini akan meningkatkan daya beli masyarakat.

Dengan berkembangnya zaman permintaan uang dipengaruhi tidak hanya pendapatan tetapi juga seperti pembayaran mudah, lebih murah dari adanya teknologi digital. Teknologi keuangan menghasilkan layanan model bisnis baru dengan kategori sistem pembayaran, manajemen investasi dan risiko, pinjaman dan pembiayaan modal dan layanan keuangan.

Metode digital payment adalah teknologi baru untuk transaksi non-tunai. Sistem transaksi ini dinilai praktis, cepat dan aman. Salah satu contoh digital payment adalah $e$-wallet, metode ini dapat digunakan untuk transaksi pembayaran dengan media smartphone. Salah satu aplikasi berbasis wallet ini adalah DANA.

DANA dengan basis open platform muncul pertama kali di Indonesia pada tahun 2018 di indonesia. Aplikasi ini dapat digunakan pada transaksi non-tunai atau non-kartu secara efisien, aman, serta mudah dalam penggunaannya.

Aplikasi DANA digunakan oleh berbagai kalangan, dari atas hingga menengah kebawah juga dapat menggunakan layanan tersebut. Meski demikian, penggunaan aplikasi ini dirasa kurang maksimal pada kalangan menengah kebawah. Hal itu terjadi karena kurangnya pemahaman terhadap fitur-fitur yang tersedia. Untuk menangani masalah 
tersebut perlu sosialisasi agar dapat memaksimalkan informasi dan cara penggunaan aplikasi ini.

Suatu teknologi dapat dikatakan berhasil jika banyak konsumen yang menggunakan teknologi tersebut. Salah satu tolak ukurnya adalah kepuasan konsumen yang merupakan titik penting dari keberhasilan suatu teknologi. Saat ini, DANA dapat dikatakan pioneer $e$-wallet di Indonesia.

Kualitas produk Menurut Hidayat (2009) adalah bentuk nilai kepuasan yang saling berhubungan. Kualitas produk memiliki ikatan pada suatu hubungan antara konsumen dengan perusahaan penyedia.

Kotler (2006: 266) menyebutkan rasa dibenak konsumen merupakan refleksi dan tertanam pada ingatan konsumen merupakan citra merek.

Konsumen yang loyal akan bekerja lebih keras untuk mendapatkan merek tersebut sebagai kesempatan yang memungkinkan untuk membayar lebih banyak perhatian untuk aktivitas pemasaran seperti iklan dan promosi (Bandyopadhyay, Gupta dan Dube 2005).

Penelitian ini bertujuan untuk memvalidasi model secara empiris dan menunjukkan bagaimana faktor tersebut dapat diterapkan sebagai alat dalam memproses manajemen merek termasuk produk dan peningkatan kualitas pelayanan.

Bakmi GM merupakan restoran dengan jaringan terbesar di Jakarta. Restoran ini berdiri pada tahun 1959. Hingga saat ini, Bakmi GM sudah memiliki 33 outlet di wilayah Jabodetabek serta terus berkembang. Bakmi GM yang ada di Bintaro Xchange beralamat di Lantai LG, Tangerang Selatan, Banten 15224. Dengan menu yang lezat dan bervariasi, Bakmi GM pantas disebut menjadi restoran andalan keluarga.

Sesuai hal tersebut, dilakukan penelitian: "Analisis pengaruh kualitas produk dan citra merek pada aplikasi DANA pada loyalitas konsumen di Bakmi GM Bintaro Xchange".

\subsection{Perumusan Masalah}

Perumusan masalah penelitian sebagai berikut:

1. Adakah pengaruh kualitas produk pada loyalitas konsumen?

2. Adakah pengaruh citra merek pada loyalitas konsumen?

\subsection{Tujuan Penelitian}

Tujuan penelitian sebagai berikut: 
1. Menganalisis pengaruh kualitas produk pada loyalitas konsumen.

2. Menganalisis pengaruh citra merek pada loyalitas konsumen.

\section{TINJAUAN PUSTAKA}

\subsection{Kualitas Produk}

Kualitas produk dalam pengertiannya adalah upaya pemenuhan kebutuhan serta keinginan konsumen dengan tujuan untuk menyeimbangkan harapan konsumen. Menurut Kotler dan Armstrong (2014: 11), kualitas produk merupakan kemampuan suatu produk untuk menampilkan fungsinya meliputi durability, reliability, akurasi, kemudahan pengoperasian, dan product improvement serta sifat lainnya. Sedangkan menurut Mowen (2012: 61), kualitas produk adalah proses evaluasi menyeluruh terhadap konsumen atas perbaikan performa suatu produk.

Kualitas produk merupakan hal penting yang mempengaruhi terjadinya kepuasan konsumen. Menurut Kotler dan Keller (2013: 153) hal penting yang menjadi landasan penjual adalah konsep produk yang berarti konsumen menyukai penjual yang menawarkan produk yang inovatif dengan kualitas yang bagus, serta kinerja terbaik. $\begin{array}{ccr}\text { Menurut Kotler } & \text { dan } & \text { Amstrong } \\ \text { (2008), strategi } & \text { potensial } & \text { untuk }\end{array}$ mengalahkan competitor adalah kualitas produk (product quality). Kualitas produk mampu memperlihatkan fungsinya seperti ketahanan, handal, ketepatan, serta kemudahan dalam penggunan.

\subsection{Citra Merek}

Menurut Aaker dan Biel (1993) citra merek adalah penilaian merek dari konsumen yang ada di pasar. Menurut Schiffman dan Kanuk (2007), citra merek merupakan kumpulan hubungan mengenai merek yang tersimpan dalam benak atau ingatan konsumen. Brand image merupakan representasi dari keseluruhan tanggapan terhadap merek serta wujud dari informasi serta pengalaman sebelumnya. Citra positif yang dimiliki konsumen terhadap merek tersebut, lebih memungkinkan untuk melakukan pembelian (Setiadi, 2003: 180). Dikemukakan lebih lanjut bahwa Brand image tidak terdapat pada teknologi, fitur, atau jenis produk tersebut, melainkan muncul karena iklan, promosi atau penggunaannya.

Menurut Setyaningsih dan Darmawan (2004) Melalui citra merek sebuah 
perusahaan dapat mengkomunikasikan ide dan pesan pada konsumen melalui produk yang dihasilkannya.

Salah satu strategi pemasaran yang penting adalah penciptaan suatu citra merek dan perlu ditangani secara serius. Citra merek akan menciptakan sebuah hubungan sentimen yang berupa kepercayaan (Nicolino, 2004). Atas hal tersebut, citra merek yang didirikan harus positif sesuai dengan harapan konsumen. Sikap positif konsumen pada merek berbanding lurus dengan tingkat pembelian konsumen terhadap merek tersebut (Seock, 2003).

\subsection{Loyalitas Konsumen}

Loyalitas konsumen merupakan upaya perusahaan dalam mempertahankan konsumen untuk tetap melakukan transaksi pembelian.

Loyalitas muncul dari kepercayaan. Menurut Shergill dan Li (2005), trust akan membentuk loyalitas pada fasilitas yang pada akhirnya juga loyal terhadap yang bersangkutan.

Menurut Gale (1997), dalam Palilati (2004) menyebutkan bahwa harapan konsumen terhadap nilai yang ditawarkan oleh suatu perusahaan mempengaruhi tingginya loyalitas konsumen.
Menurut Griffin (2002), konsumen yang sangat puas dengan prduk atau jasa tertentu merupakan konsumen yang loyal. Konsumen tersebut memiliki minat untuk mengenalkan atau menyebarkan kepada siapapun. Terdapat karakteristik konsumen yang loyal antara lain:

1. Membeli secara berulang dan teratur.

2. Melakukan pembelian diluar lini.

3. Melakukan penolakan terhadap produk atau jasa yang lain.

4. Tidak terpengaruh oleh pesaing.

5. Menarik pelanggan baru.

6. Memberitahukan kekurangan hanya kepada perusahaan.

Loyalitas konsumen adalah hal strategis yang harus dikelola dengan baik oleh perusahaan sehingga dapat memberikan nilai lebih seperti reduksi pemasaran, mendapatkan konsumen baru, dan meningkatkan pertahanan terhadap persaingan (Taylor et al., 2004).

\subsection{Kerangka Pemikiran}

Loyalitas ditunjukkan oleh adanya pembelian produk/ jasa pada perusahaan yang sama (Casalo, Flavian, dan Guinaliu, 2008). Loyalitas ditentukan oleh kepercayaan konsumen terhadap perusahaan (Hoq, Sultana, dan Ami, 2010). 
JURNAL ПMПAH

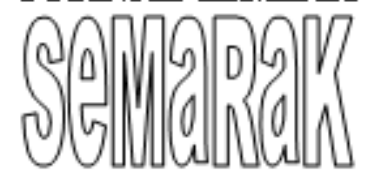

Loyalitas terbentuk melalui pembentukan keadilan di dalam penyampaian layanan jasa kepada konsumen (Lee, Joshi, dan Kim, 2011). Nilai konsumen memperlihatkan persepsi perbandingan apa yang diberikan dengan yang diterima (Anuwichanont dan Mechinda, 2009). Persepsi mengenai nilai yang diterima oleh konsumen menjadi salah satu alasan untuk melakukan transaksi pada suatu perusahaan penyedia jasa (Sabiote et al., 2012).

Menurut pengungkapan (Haryantini, 2019) ada korelasi antara dua nilai yang dirasakan yaitu kualitas produk dan citra merek pada loyalitas konsumen.

Gambar 2.1 Kerangka konseptual

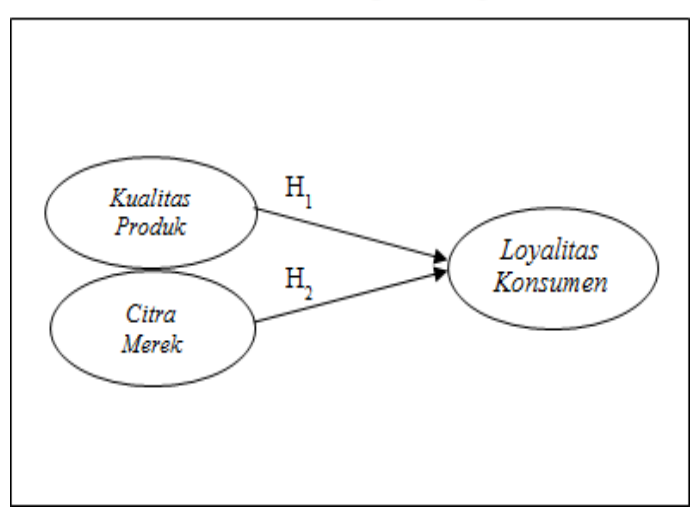

III. METODOLOGI PENELITIAN

\subsection{Rancangan Penelitian}

Penelitian ini mengacu pada penelitian yang telah dilakukan oleh Haryantini, 2019 yang menganalisis loyalitas konsumen
P-ISSN 2615-6849, E-ISSN 2622-3686

@ Prodi Manajemen Fakultas Ekonomi Universitas Pamulang

\subsection{Variabel dan pengukuran}

\subsubsection{Variabel}

Variabel penelitian terdiri dari:

1. Variabel Bebas (Independent Variable)

Variabel bebas yang mempengaruhi variabel terikat yaitu kualitas produk dan citra merek.

A. Kualitas Produk

Telah digunakan seperti yang diungkapkan oleh (Garvin, 2012) sebagai berikut:

1) Produk pembayaran digital DANA memiliki kualitas yang baik dalam fitur maupun dalam kemudahan penggunaan.

2) Produk pembayaran digital DANA lebih baik dari segi produk atau pelayanan.

3) Produk pembayaran digital DANA memiliki sistem keamanan yang baik. 
B. Citra Merek

Telah dioperasionalisasikan yang diungkapkan oleh (Davidson dalam Tjiptono, 2014) sebagai berikut:

1) Merek dompet digital DANA memiliki reputasi yang baik.

2) Merek dompet digital DANA mudah diingat dan mudah dikenali.

3) Konsumen memiliki kebanggaan pada saat pemakaian aplikasi DANA karena kemudahannya dan keamanannya.

2. Variabel terikat (Dependent Variable)

Variabel terikat yang dipengaruhi oleh variabel bebas yaitu loyalitas konsumen.

\section{A. Loyalitas Konsumen}

Telah digunakan seperti yang diungkapkan oleh (Tjiptono, 2011) sebagai berikut:

1) Aplikasi dompet digital DANA di Bakmi GM Bintaro Xchange memenuhi harapan setiap konsumen yang ingin bertransaksi.

2) Konsumen merasa yakin terhadap Aplikasi dompet digital DANA di Bakmi GM Bintaro Xchange sehingga tetap menggunakan produk ini walaupun ada merek lain.

3) Aplikasi dompet digital DANA di Bakmi GM Bintaro Xchange memiliki kredibilitas yang baik sehingga konsumen melakukan transaksi yang berulang pada waktu lain dengan menggunakan aplikasi DANA.

\subsection{Populasi dan Sampel Penelitian}

Populasi merupakan keseluruhan subyek penelitian. Populasi penelitian ini adalah konsumen di Bakmi GM Bintaro Xchange yang menggunakan aplikasi DANA.

Pengumpulan sampel dilakukan secara non-random sampling. Diambil berdasarkan berbagai penilaian dan dipilih sesuai standar tertentu (Sekaran, 2006). Untuk menentukan jumlah sampel meggunakan rumus sebagai berikut:

$\mathrm{n}=\frac{\mathrm{N}}{1+\mathrm{N}(\mathrm{e})^{2}}$

$\mathrm{n}=\frac{132}{1+132(0,05)^{2}}$

$\mathrm{n}=100$

Dimana:

$\mathrm{n}$ = Jumlah sampel

$\mathrm{N}=$ Jumlah populasi 
JURNAL ПMПAH

$\mathrm{e}=$ Error margin

Berdasarkan rumus slovin tersebut, diedarkan kuesioner kepada 100 konsumen di Bakmi GM Bintaro Xchange yang menggunakan aplikasi DANA dari 132 konsumen sebagai populasi yang ada.

\subsection{Metode Pengumpulan Data}

Data diambil sesuai tujuan penelitian, kemudian diolah untuk mendapatkan kesimpulan. Sumber berasal dari:

1. Penelitian Lapangan (Data Primer)

Untuk mendapatkan data, peneliti mendatangi tempat yang menjadi obyek. Peneliti menggunakan kuesioner sebagai media pengumpulan sampel.

2. Penelitian Kepustakaan (Data Sekunder)

Peneliti meggunakan buku dan jurnal yang secara teoritis meneliti variabel ketiga variabel tersebut.

\subsection{Metode Analisis Data}

Metode analisis adalah kuantitatif yaitu angka-angka yang dapat dihitung dan diukur. Pengolahan data pada metode ini melalui beberapa tahap.

\subsubsection{Uji Validitas}

Untuk mendapatkan hubungan tiap indikator terhadap skor totalnya digunakan teknik pearson correlation, sehingga
P-ISSN 2615-6849, E-ISSN 2622-3686

@ Prodi Manajemen Fakultas Ekonomi Universitas Pamulang

diketahui validitasnya. Dasar pengambilan keputusan:

- Nilai pearson <0,05: valid.

- Nilai pearson >0,05: tidak valid.

\subsubsection{Uji Reabilitas}

Untuk menentukan konsistensi, akurasi, dan predictable variabel yang digunakan dengan melihat koefisien Cronbach's Alpha. Dasar pengambilan keputusan:

- Nilai koefisien >0,6: reliable.

- Nilai koefisien <0,6: tidak reliable.

\subsubsection{Analisa Regresi Berganda}

Untuk mengetahui pengaruh positif kualitas produk dan citra merek pada loyalitas konsumen.

Bentuk persamaan sebagai berikut: $\mathrm{Y}=\alpha+\left(\beta_{\mathrm{KPX}} \mathrm{X}_{\mathrm{KP}}\right)+\left(\beta_{\mathrm{CM} X} \mathrm{X}_{\mathrm{CM}}\right)$

Keterangan:

Y = Loyalitas konsumen

$\alpha=$ Konstanta

$\beta_{\mathrm{KP}}, \beta_{\mathrm{CM}}=$ Koefisien estimasi

$\mathrm{X}_{\mathrm{KP}} \quad=$ Kualitas produk

$\mathrm{X}_{\mathrm{CM}} \quad=$ Citra merek

\subsubsection{Uji Hipotesis}

1. Uji t

Untuk melihat apakah tiap variabel bebas mempengaruhi variabel terikat secara terpisah. Hipotesis sebagai berikut: 
- Signifikasi <0,05: terdapat pengaruh signifikan variabel bebas pada variabel terikat.

- Signifikasi >0,05: tidak terdapat pengaruh signifikan variabel bebas pada variabel terikat.

\section{Uji Goodness of Fit (Uji F dan $\mathbf{R}^{2}$ )}

Untuk mengukur kesesuaian sampel antara harapan dengan aktual digunakan:

A. Uji F (Uji Simultan)

Untuk melihat apakah semua variabel bebas memiliki pengaruh pada variabel terikat secara simultan. Hipotesis sebagai berikut:

- Signifikansi <0,05: terdapat pengaruh signifikan variabel bebas pada variabel terikat secara simultan.

- Signifikansi >0,05: tidak terdapat pengaruh signifikan variabel bebas pada variabel terikat secara simultan.

B. Koefisien Determinasi $\left(\mathrm{R}^{2}\right)$

Untuk menaksir kesanggupan pola dalam menjelaskan variasi variabel terikat. Nilai $\mathrm{R}^{2}$ adalah $0<\mathrm{R}^{2}<1$. adjusted $R$ square apabila mendapat tambahan variabel bebas nilainya dapat berubah. Oleh karena itu, untuk mendapatkan model regresi terbaik digunakan nilai adjusted $R$ square (Ghozali, 2006).

IV. ANALISA DAN PEMBAHASAN

\subsection{Profil dan Analisis Indeks Jawaban} Responden Per Variabel

\subsubsection{Profil Responden}

Hasil ditampilkan pada tabel sebagai berikut:

Tabel 4.1 Profil Responden

\begin{tabular}{|c|c|c|c|}
\hline $\mathrm{N}_{0}$ & Profil Responden & Jumlah & $\begin{array}{c}\text { Persentase } \\
(\%)\end{array}$ \\
\hline 1. & $\begin{array}{l}\text { Jenis Kelamin: } \\
\text { a. Pria } \\
\text { b. Wanita }\end{array}$ & $\begin{array}{l}57 \\
43\end{array}$ & $\begin{array}{l}57 \% \\
43 \%\end{array}$ \\
\hline 2. & $\begin{array}{l}\text { Alasan konsumen percaya terhadap } \\
\text { penggunaan Aplikasi Dana di } \\
\text { Bakmi GMBintaro Xchange: } \\
\text { a. Layanan Berkualitas } \\
\text { b. Kemudahan dan kenyamanan } \\
\text { dalam transaksi pembayaran } \\
\text { c. Cashback dalam setiap transaksi } \\
\text { pembayaran }\end{array}$ & $\begin{array}{l}15 \\
48\end{array}$ & $\begin{array}{l}15 \% \\
48 \% \\
37 \%\end{array}$ \\
\hline 3. & $\begin{array}{l}\text { Pendidikan Terakhir: } \\
\text { a. Diploma } 3 \\
\text { b. Sarjana Strata } 1(\mathrm{~S} 1) \\
\text { c. Pasca Sarjana (S2) } \\
\text { d. Lainnya... }\end{array}$ & $\begin{array}{r}17 \\
58 \\
22 \\
3\end{array}$ & $\begin{array}{r}17 \% \\
58 \% \\
22 \% \\
3 \%\end{array}$ \\
\hline 4. & $\begin{array}{l}\text { Lama menjadi konsumen Bakmi } \\
\text { GM Bintaro Xchange: } \\
\text { a. 2-3 Tahun } \\
\text { b. 4-5 Tahun } \\
\text { c. > } 6 \text { Tahun }\end{array}$ & $\begin{array}{l}33 \\
30\end{array}$ & $\begin{array}{l}37 \% \\
33 \% \\
30 \%\end{array}$ \\
\hline
\end{tabular}

responden dilihat dari jenis kelamin, alasan konsumen percaya terhadap aplikasi DANA di Bakmi GM Bintaro Xchange, pendidikan terakhir serta lama menjadi 
konsumen Bakmi GM Bintaro Xchange dapat disimpulkan bahwa konsumen Bakmi GM Bintaro Xchange didominasi oleh lakilaki, mayoritas responden konsumen Bakmi GM Bintaro Xchange setuju bahwa saran yang diberikan sesuai dengan kebutuhan konsumen akan kemudahan dan kenyamanan melakukan transaksi pembayaran, pendidikan terakhir konsumen Bakmi GM Bintaro Xchange mayoritas adalah Sarjana Strata 1 (S1). Lama menjadi konsumen Bakmi GM Bintaro Xchange mayoritas adalah 2-3 Tahun.

\subsubsection{Analisis Indeks Jawaban Responden Per} Variabel

Untuk melihat tanggapan responden terhadap variabel kuesioner, digunakan rumus sebagai berikut:

$\mathrm{X}=\left(\left(1 \times \sum 1\right)+\left(2 \times \sum 2\right)+\left(3 \times \sum 3+\left(4 \times \sum 4\right)+(5 \times\right.\right.$

$\left.\left.\sum 5\right)\right) / 5$

Keterangan:

- $\mathrm{X}=$ Nilai Indeks

- $\sum 1=$ jumlah yang menjawab STS (1)

- $\sum 2=$ jumlah yang menjawab TS (2)

- $\sum 3=$ jumlah yang menjawab N (3)

- $\sum 4=$ jumlah yang menjawab S (4)

- $\sum 5=$ jumlah yang menjawab SS (5)
Skor jawaban dimulai dari angka 1-5. Untuk jumlah responden 100 orang diperoleh:

- Batas atas $=(5 \times n) / 5=(5 \times 100) / 5=100$

- Batas bawah $=(1 \times n) / 5=(1 \times 100) / 5=20$

Dengan menggunakan kriteria 3 kotak diperoleh:

- Rentang $=$ batas atas - bawah $100=100-$ $20=80$

- Rentang tiap bagian $=80 / 3=26,67$

Sesuai perhitungan diatas, indeks persepsi responden terhadap variabel sebagai berikut:

$\begin{array}{ll}\text { Tinggi } & =73,35-100 \\ \text { Sedang } & =46,68-73,34 \\ \text { Rendah } & =20-46.67\end{array}$

Tanggapan responden dalam hal ini ditampilkan berdasarkan pada indikator ketiga variable penelitian. Analisa sebagai berikut:

\section{Analisis Indeks Jawaban Variabel}

\section{Kualitas Produk}

Tabel 4.2 Frekuensi Jawaban Variabel Kualitas Produk

\begin{tabular}{|c|c|c|c|c|}
\hline Nilai & KP1 & KP2 & KP3 & Total \\
\hline 1 & 0 & 0 & 0 & 0 \\
\hline 2 & 0 & 0 & 0 & 0 \\
\hline 3 & 16 & 18 & 18 & 52 \\
\hline 4 & 73 & 76 & 74 & 223 \\
\hline 5 & 11 & 6 & 8 & 25 \\
\hline Total & 100 & 100 & 100 & $\mathbf{3 0 0}$ \\
\hline Indeks & $\mathbf{7 9}$ & $\mathbf{7 7 . 6}$ & $\mathbf{7 8}$ & $\mathbf{7 8 . 2}$ \\
\hline
\end{tabular}

Kesimpulan: 
- KP1 memiliki nilai indeks 79, indikator Produk pembayaran digital DANA memiliki kualitas yang baik dalam fitur maupun dalam kemudahan penggunaan adalah tinggi.

- KP2 memiliki nilai indeks 77,6, indikator Produk pembayaran digital DANA lebih baik dari segi produk atau pelayanan adalah tinggi.

- KP3 memiliki nilai indeks 78, indikator Produk pembayaran digital DANA memiliki sistem keamanan yang baik adalah tinggi.

Nilai indeks variabel kualitas produk adalah 78,4 (tinggi).

\section{Analisis Indeks Jawaban Variabel}

\section{Citra Merek}

Tabel 4.3 Frekuensi Jawaban Variabel Citra Merek

\begin{tabular}{|c|c|c|c|c|}
\hline Nilai & CMl & CM2 & CM3 & Total \\
\hline 1 & 0 & 0 & 0 & 0 \\
\hline 2 & 0 & 0 & 0 & 0 \\
\hline 3 & 17 & 19 & 18 & 54 \\
\hline 4 & 72 & 74 & 76 & 222 \\
\hline 5 & 11 & 7 & 6 & 24 \\
\hline Total & $\mathbf{1 0 0}$ & $\mathbf{1 0 0}$ & $\mathbf{1 0 0}$ & $\mathbf{3 0 0}$ \\
\hline Indeks & $\mathbf{7 8 . 8}$ & $\mathbf{7 7 . 6}$ & $\mathbf{7 7 . 6}$ & $\mathbf{7 8}$ \\
\hline
\end{tabular}

Kesimpulan:

- CM1 memiliki nilai indeks 78,8, indikator Merek dompet digital DANA memiliki reputasi yang baik adalah tinggi.
- CM2 memiliki nilai indeks 77,6, indikator Merek dompet digital DANA mudah diingat dan mudah dikenali adalah tinggi.

- CM3 memiliki nilai indeks 77,6, indikator Konsumen memiliki kebanggaan pada saat pemakaian aplikasi DANA karena kemudahannya dan keamanannya adalah tinggi.

Nilai indeks variabel citra merek adalah 78 (tinggi).

\section{Analisis Indeks Jawaban Variabel}

\section{Loyalitas Konsumen}

Tabel 4.4 Frekuensi Jawaban Variabel Loyalitas Konsumen

\begin{tabular}{|c|c|c|c|c|}
\hline Nilai & LKl & LK2 & LK3 & Total \\
\hline 1 & 0 & 0 & 0 & 0 \\
\hline 2 & 0 & 0 & 0 & 0 \\
\hline 3 & 18 & 18 & 16 & 52 \\
\hline 4 & 75 & 73 & 72 & 220 \\
\hline 5 & 7 & 9 & 12 & 28 \\
\hline Total & 100 & 100 & 100 & $\mathbf{3 0 0}$ \\
\hline Indeks & $\mathbf{7 7 . 8}$ & $\mathbf{7 8 . 2}$ & $\mathbf{7 9 . 2}$ & $\mathbf{7 8 . 4}$ \\
\hline
\end{tabular}

Kesimpulan:

- LK1 memiliki nilai indeks 77,8 , indikator Aplikasi dompet digital DANA di Bakmi GM Bintaro Xchange memenuhi harapan setiap konsumen yang ingin bertransaksi adalah tinggi.

- LK2 memiliki nilai indeks 78,2, indikator Konsumen merasa yakin 
terhadap Aplikasi dompet digital DANA di Bakmi GM Bintaro Xchange sehingga tetap menggunakan produk ini walaupun ada merek lain adalah tinggi.

- LK3 memiliki nilai indeks 79,2, indikator Aplikasi dompet digital DANA di Bakmi GM Bintaro Xchange memiliki kredibilitas yang baik sehingga konsumen melakukan transaksi yang berulang pada waktu lain dengan menggunakan aplikasi DANA adalah tinggi.

Nilai indeks variabel loyalitas konsumen adalah 78,4 (tinggi).

\subsection{Analisa Data}

\subsubsection{Hasil Uji Validitas}

Hasil uji ditampilkan pada tabel berikut: Tabel 4.5 Uji Validitas

\begin{tabular}{|l|c|c|c|}
\hline \multicolumn{1}{|c|}{ Variabel dan Pernyataan } & $\begin{array}{c}\text { P- } \\
\text { Value }\end{array}$ & $\begin{array}{c}\text { Coefficient } \\
\text { Correlation }\end{array}$ & Keputusan \\
\hline l. Kualitas Produk & 0.884 & Valid \\
\hline $\begin{array}{l}\text { Produk pembayaran digital DANA } \\
\text { memiliki kualitas yang baik dalam } \\
\text { fitur maupun dalam kemudahan } \\
\text { penggunaan }\end{array}$ & 0.000 & & \\
\hline $\begin{array}{l}\text { Produk pembayaran digital DANA } \\
\text { lebih baik dari segi produk atau } \\
\text { pelayanan }\end{array}$ & 0.000 & 0.887 & Valid \\
\hline $\begin{array}{l}\text { Produk pembayaran digital DANA } \\
\text { memiliki sistem keamanan yang } \\
\text { baik }\end{array}$ & 0.000 & 0.939 & Valid \\
\hline 2. Citra Merek digital DANA & 0.000 & 0.911 & Valid \\
\hline $\begin{array}{l}\text { Merek dompet } \\
\text { memiliki reputasi yang baik }\end{array}$ & 0.926 & Valid \\
\hline $\begin{array}{l}\text { Merek dompet digital DANA } \\
\text { mudah dingat dan mudah dikenali }\end{array}$ & 0.000 & & \\
\hline $\begin{array}{l}\text { Konsumen memiliki kebanggaan } \\
\text { pada saat pemakaian aplikasi }\end{array}$ & 0.000 & 0.935 & Valid \\
$\begin{array}{l}\text { DANA karena kemudahannya dan } \\
\text { keamanannya }\end{array}$ & & \\
\hline
\end{tabular}

\begin{tabular}{|l|l|l|l|}
\hline 3. Loyalitas Konsumen \\
\hline $\begin{array}{l}\text { Aplikasi dompet digital DANA di } \\
\text { Bakmi GM Bintaro Xchange } \\
\text { memenuhi harapan setiap } \\
\text { konsumen yang ingin bertransaksi }\end{array}$ & 0.000 & 0.897 & Valid \\
\hline $\begin{array}{l}\text { Konsumen merasa yakin terhadap } \\
\text { Aplikasi dompet digital DANA di } \\
\text { Bakmi GM Bintaro Xchange } \\
\text { sehingga tetap menggunakan } \\
\text { produk ini walaupun ada merek }\end{array}$ & 0.000 & 0.919 & Valid \\
lain & & \\
\hline $\begin{array}{l}\text { Aplikasi dompet digital DANA di } \\
\text { Bakmi GM Bintaro Xchange } \\
\text { memiliki kredibilitas yang baik } \\
\text { sehingga konsumen melakukan } \\
\text { transaksi yang berulang pada waktu }\end{array}$ & 0.000 & 0.894 & Valid \\
lain dengan menggunakan aplikasi \\
DANA
\end{tabular}

Terlihat pada tabel bahwa nilai pearson tiap item indikator ketiga variabel 0,000 $(<0,05)$. Artinya seluruh item indikator valid dan dapat diukur.

\subsubsection{Hasil Uji Reabilitas}

Hasil uji ditampilkan pada tabel berikut:

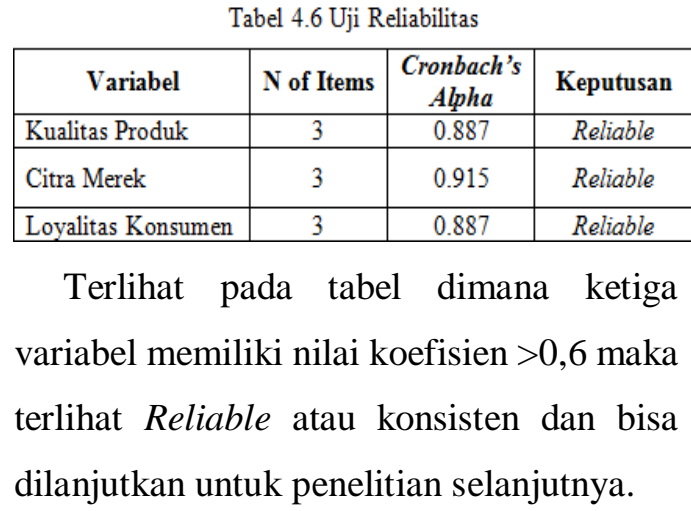


JURNAL ПMПAH

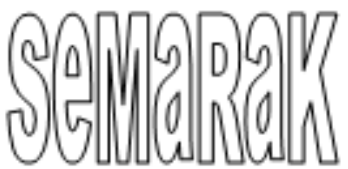

\subsubsection{Hasil Analisa Regresi Berganda}

Hasil uji ditampilkan pada tabel berikut:

Tabel 4.7 Uji Regresi Berganda

Coefficients $^{8}$

\begin{tabular}{|c|c|c|c|c|}
\hline \multicolumn{5}{|c|}{ Coefficlents ${ }^{3}$} \\
\hline \multirow{2}{*}{\multicolumn{2}{|c|}{ Model }} & \multicolumn{2}{|c|}{ Unstandardized Coefficients } & \multirow{2}{*}{$\begin{array}{c}\text { Standardized } \\
\text { Coefficients }\end{array}$} \\
\hline & & $\mathrm{B}$ & Std. Error & \\
\hline 1 & (Constant) & 1.130 & 1.099 & \\
\hline & KP & .571 & .075 & .558 \\
\hline & $\mathrm{CM}$ & .336 & .073 & .337 \\
\hline
\end{tabular}

a. DependentVariable:LK

Bentuk persamaan sebagai berikut:

$\mathrm{Y}=1,130+0,558 \mathrm{X}_{\mathrm{KP}}+0,337 \mathrm{X}_{\mathrm{CM}}$

Kesimpulan:

- Terdapat pengaruh positif variabel kualitas produk $\left(\mathrm{X}_{\mathrm{KP}}\right)$ pada loyalitas konsumen (Y) sebesar 0,558.

- Terdapat pengaruh positif variabel citra merek $\left(\mathrm{X}_{\mathrm{CM}}\right)$ pada loyalitas konsumen (Y) sebesar 0,337.

\subsubsection{Hasil Uji Hipotesis}

\section{Hasil Uji t}

Hasil uji ditampilkan pada tabel berikut:

\begin{tabular}{|c|c|c|c|c|c|}
\hline \multicolumn{6}{|c|}{$\begin{array}{l}\text { Tabel } 4.8 \mathrm{Uji} \mathrm{t} \\
\text { Coefficients }^{\mathrm{a}}\end{array}$} \\
\hline \multirow{2}{*}{\multicolumn{2}{|c|}{ Model }} & \multirow[b]{2}{*}{$t$} & \multirow[b]{2}{*}{ Sig. } & \multicolumn{2}{|c|}{ Collinearity Statistics } \\
\hline & & & & Tolerance & VIF \\
\hline \multirow[t]{3}{*}{1} & (Constant) & 1.028 & .306 & & \\
\hline & KP & 7.623 & .000 & .959 & 1.043 \\
\hline & $\mathrm{CM}$ & 4.596 & .000 & .959 & 1.043 \\
\hline
\end{tabular}

a. DependentVariable:LK

Kesimpulan:
P-ISSN 2615-6849, E-ISSN 2622-3686

@ Prodi Manajemen Fakultas Ekonomi Universitas Pamulang
- Signifikasi variabel kualitas produk (KP) 0,000 $(<0,05)$. Terdapat pengaruh signifikan variabel kualitas produk pada loyalitas konsumen.

- Signifikasi variabel citra merek (CM) $0,000 \quad(<0,05)$. Terdapat pengaruh signifikan variabel citra merek pada loyalitas konsumen.

\section{Hasil Uji Goodness of Fit (Uji F dan $\mathbf{R}^{2}$ )}

A. Hasil Uji F (Uji Simultan)

Hasil uji ditampilkan pada tabel berikut:

\section{Tabel 4.9 Uji F}

\begin{tabular}{|l|r|r|r|r|r|}
\hline \multicolumn{7}{|c|}{ ANOVA $^{\mathrm{b}}$} \\
\hline Model & Sum of Squares & df & Mean Square & F & Sig. \\
\hline Regression & 95.373 & 2 & 47.686 & 48.758 & .000 \\
Residual & 94.867 & 97 & .978 & & \\
Total & 190.240 & 99 & & & \\
\hline
\end{tabular}

a. Predictors: (Constant), CM, KP

b. DependentVariable:LK

Terlihat pada tabel signifikansi 0,000 $(<0,05)$. Terdapat pengaruh signifikan variabel kualitas produk dan citra merek pada variabel loyalitas konsumen secara simultan.

B. Hasil Koefisien Determinasi $\left(\mathrm{R}^{2}\right)$

Hasil uji ditampilkan pada tabel berikut: 
Tabel 4.10 Koefisien Determinasi $\left(\mathrm{R}^{2}\right)$

Model Summary

\begin{tabular}{|l|r|r|r|r|}
\hline Model & \multicolumn{1}{|c|}{$R$} & R Square & \multicolumn{1}{c|}{$\begin{array}{c}\text { Adjusted } R \\
\text { Square }\end{array}$} & $\begin{array}{c}\text { Std. Error of the } \\
\text { Estimate }\end{array}$ \\
\hline 1 & $.708^{\mathrm{a}}$ & .501 & .491 & .989 \\
\hline
\end{tabular}

a. Predictors: (Constant), $\mathrm{CM}, \mathrm{KP}$

Terlihat pada tabel besarnya Adjusted $R$ Square 0,491. Hal ini berarti $49.1 \%$ variabel loyalitas konsumen $(\mathrm{Y})$ dapat dijelaskan oleh variabel bebas.

\subsection{Pembahasan}

Sesuai dengan data pada analisa regresi berganda dan uji hipotesis, diperoleh informasi sebagai berikut:

1. Hipotesis pertama $\left(\mathrm{H}_{1}\right)$ diterima. Hal ini terlihat dari koefisien variabel kualitas produk sebesar 0,558 , serta signifikansi sebesar 0,000 $(<0,05)$. Dapat dijelaskan bahwa fitur, kemudahan penggunaan, pelayanan dan sistem keamanan yang baik akan dapat meningkatkan loyalitas konsumen pada produk tersebut.

2. Hipotesis kedua $\left(\mathrm{H}_{2}\right)$ diterima. Hal ini terlihat dari koefisien variabel citra merek sebesar 0,337 , serta signifikansi sebesar 0,000 (kurang dari 0,05). Dapat dijelaskan bahwa produk dengan reputasi yang baik, mudah diingat dan mudah dikenali, serta memiliki kebanggaan pada saat digunakan akan dapat meningkatkan loyalitas konsumen pada produk tersebut.

\section{PENUTUP}

\subsection{Kesimpulan}

Dari hasil penelitian dan analisis pengaruh kualitas produk dan citra merek pada loyalitas konsumen yang menggunakan aplikasi DANA di Bakmi GM Bintaro Xchange maka ditarik kesimpulan sebagai berikut:

1. Persamaan regresi yang diperoleh:

$$
\mathrm{Y}=1,130+0,558 \mathrm{X}_{\mathrm{KP}}+0,337 \mathrm{X}_{\mathrm{CM}}
$$

2. Pernyataan hipotesis pertama $\left(\mathrm{H}_{1}\right)$ yang menyatakan bahwa terdapat pengaruh positif dan signifikan antara kualitas produk pada loyalitas konsumen terbukti kebenarannya.

3. Pernyataan hipotesis kedua $\left(\mathrm{H}_{2}\right)$ yang menyatakan bahwa terdapat pengaruh positif dan signifikan antara citra merek pada loyalitas konsumen terbukti kebenarannya.

4. Terdapat pengaruh secara bersama-sama (simultan) antara kualitas produk dan citra merek pada loyalitas konsumen terbukti kebenarannya. Hal ini terlihat dari Uji $\mathrm{F}$ dengan angka signifikansi sebesar $0,000(<0,05)$. 
JURNAL ПMПAH

Samidaing

\subsection{Saran}

Sesuai dengan hasil penelitian, saran kepada pihak aplikasi DANA sebagai berikut:

1. Variabel kualitas produk memberikan pengaruh tertinggi pada loyalitas konsumen, oleh karena itu tetap menjaga dan meningkatkan kualitas produknya terutama pada bagian fitur, kemudahan penggunaan, pelayanan dan sistem keamanan.

2. Pihak DANA tetap menjadikan DANA sebagai merek yang mudah diingat dan dikenali. Selain itu pihak DANA diharapkan tetap menjaga reputasi yang baik sehingga konsumen memiliki kebanggaan pada saat menggunakan produk tersebut.

\section{DAFTAR PUSTAKA}

Aaker, David A. and Alexander, L. Biel. (1993). Managing Brand Equity: Capitalizing on The Value of Brand Name. Free Press:New York.

Arianto, N. (2020). Pengaruh Kualitas Produk dan Harga Terhadap Keputusan Pembelian. Jurnal Pemasaran Kompetitif, 3(2), 12-22.
P-ISSN 2615-6849, E-ISSN 2622-3686

@ Prodi Manajemen Fakultas Ekonomi Universitas Pamulang

Bertea, P. E., Moisescu, O. I. (2010). Investigating the Role of Brand Awareness in Reducing the Perceived Risk Associated to online Buying of Tourism Services, International Conference Marketing - from information to decision, Vol. 3, pp. (918).

Chahal, H., Bala, M. (2010). Confirmatory study on brand equity and brand loyalty: A special look at the impact of attitudinal and behavioural loyalty vision, Vol. 14 No (1), pp. (1- 12).

Chen, A. C. H. (2001). Using free association to examine the relationship between the characteristics of brand association and brand equity. Journal of Product \& Brand Management, Vol. 10 No. 7, pp. $439-451$.

Coop, W. F. (2002). Brand image of MBA business schools in South Africa as driver of customer-based brand equity. Unpublished Master's dissertation, Cape Technikon, Cape Town. 
JURNAL ПMПAH

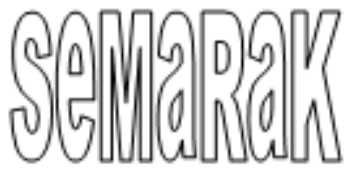

Faircloth, J.B., Capella, L. M., Alford, B. L. (2001). The effect of brand attitude and brand image on brand equity. Journal of Marketing Theory and Practice 9 (3), pp. $61-74$.

Farquhar, P. (2003). Editorial: uncovering brand gremlins and other hidden perils. Journal of Brand Management, Vol. 10 No. 6, pp. 388-392.

Haryantini. (2019). Pengaruh citra merek dan promosi terhadap loyalitas pelanggan Gojek di stasiun Depok Jawa Barat. Jurnal Pemasaran Kompetitif, 3(1), 46-54.

Haryoko, U. B., Pasaribu, V. L. D., \& Ardiyansyah, A. (2020). PENGARUH HARGA DAN KUALITAS PELAYANAN TERHADAP KEPUASAN KONSUMEN PADA FIRMAN DEKORASI (WEDDING ORGANIZER). POINT, 2(1).

PASARIBU, V. L. D. (2017). ANALISIS PENGARUH PROMOSI, KUALITAS PRODUK DAN DESAIN KEMASAN TERHADAP PERSEPSI MEREK YANG BERDAMPAK KEPADA KEPUTUSAN PEMBELIAN HAND AND BODY LOTION MEREK VASELINE (Studi Kasus TIP TOP Ciputat, Tangerang Selatan). INOVASI, 4(2).
P-ISSN 2615-6849, E-ISSN 2622-3686

$@$ Prodi Manajemen Fakultas Ekonomi Universitas Pamulang

Pasaribu, V. L. D. (2020). ANALISIS PENGARUH PROMOSI, KUALITAS PRODUK DAN DESAIN KEMASAN TERHADAP KEPUTUSAN PEMBELIAN HAND AND BODY LOTION MEREK CITRA (Studi Kasus Carrefour Pamulang, Tangerang Selatan). Jurnal Pemasaran Kompetitif, 1(4).

Pasaribu, V. L. D., \& Prayoga, M. Y. S. (2019). Pengaruh Kualitas Produk Baju Batik Hem Terhadap Kepuasan Pelanggan Pada Home Industri Batik Sahara Indah. Jurnal Pemasaran Kompetitif, 2(2), 77-83.

Pasaribu, V. L. D. PENGARUH STORE ATMOSPHERE TERHADAP KEPUTUSAN PEMBELIAN PADA RESTORAN DE'COST GIANT PAMULANG SQUARE TANGERANG SELATAN. Manajerial: Jurnal Manajemen dan Sistem Informasi, 19(2), 156-167.

Rr Anggraini, R. (2019). Faktor-faktor yang mempengaruhi customer loyalty pada konsumen reksadana autoinvest di Bank Commonwealth Jakarta. Jurnal Ilmiah Manajemen, 2(2), 83-95. 